\title{
The Impact of Electoral Violence on Economic Development: A Case of Kenya
}

\author{
Okech Achieng Matilda \\ Department of International Development, University of Birmingham, Birmingham, United Kingdom \\ Email address: \\ matildaokech2002@yahoo.com \\ To cite this article: \\ Okech Achieng Matilda. The Impact of Electoral Violence on Economic Development: A Case of Kenya. Journal of Political Science and \\ International Relations. Vol. 1, No. 3, 2018, pp. 55-71. doi: 10.11648/j.jpsir.20180103.11
}

Received: December 29, 2018; Accepted: February 7, 2019; Published: February 26, 2019

\begin{abstract}
Highly contested elections are characterised by electoral violence and high levels of uncertainty that negatively impact on economic activities of the country. This is was a descriptive study. A case study design employed both qualitative and quantitative approaches to explore the impacts of electoral violence on economic development of Kenya by examining data during and after election periods. Quantitative data was derived from a desk review of economic monitor indicators from World Bank database and the Kenya National Bureau of Statistics for the period between 1990 and 2017. Qualitative data was from in-depth interviews which were conducted with five business individuals by use of a semi-structured interview guide. Comparative analysis of the data was done on an annual and monthly basis. Comparative analysis was also done for years of peaceful elections and years that experienced electoral violence. The findings suggested that electoral month was significantly affected by electoral violence in comparison to the electoral year. Economic activities remained stable and even increased during the years of peaceful elections in comparison to years of electoral violence. The findings revealed that significant economic development can be achieved with peaceful elections and therefore there is need to halt electoral violence through creation of awareness on the importance of embracing peaceful elections and its impact on the economy.
\end{abstract}

Keywords: Elections, Electoral Violence, Economic Development, Economic Monitor Indicators

\section{Introduction}

Kenya gained independence in 1963 and embraced the Westminster style of democracy involving multi-party and a federal government and quickly the country introduced a more centralised presidential system of governance [13]. The country has gradually shaped its system of governance that was once marked with banning of political parties after an attempted coup in 1982 and later reintroduction of multiparty democracy in 1991 [39]. Constitutional reforms, civil society activists and International Community have greatly contributed to the democratic milestones the country has achieved over the years [11,39].

Kenya is a regional player in the East Africa Community as it enjoys economic leverage of the Indian Ocean port. It has strategic boarder locations with Ethiopia to the North, South Sudan to the Northwest, Uganda to the West, Tanzania to the South and Southwest and Somalia to the Northeast [36]. Kenya covers $581,646 \mathrm{~km}^{2}$ and as at 2016 , it had a population of 45.4million [15]. According to the World Bank
2016 statistics, Kenya ranked the highest within the East Africa Community with a GDP per capita of 1,455.4.

Electoral violence is "any random or organized act that seeks to determine, delay, or otherwise influence an electoral process through threat, verbal intimidation, hate speech, disinformation, physical assault, forced "protection," blackmail, destruction of property, or assassination" [54]. UNDP [85] also defines electoral violence as "acts or threats of coercion, intimidation, or physical harm perpetrated to affect an electoral process or that arise in the context of electoral competition. When perpetrated to affect an electoral process, violence may be employed to influence the process of elections - such as efforts to delay, disrupt, or derail a poll - and to influence the outcomes: the determining of winners in competitive races for political office or to secure approval or disapproval of referendum questions". The above definitions denote a threat or actual violence that interferes with the electoral process with an aim of influencing the outcome of an election. Electoral violence is therefore a broad concept influenced by many factors. This research 
focused on a free and fair election which has been of public interest in Kenya.

Elections as a tool of democratic participation has been highly contested in Africa since post-independence due to the quest for leadership, power and access to resources the political positions are associated with [22]. In Kenya, since the onset of multi-party election in 1992, elections have been highly contested and there has been an increase in the trend of electoral violence in the past six elections save for 2002 elections which was characterised by smooth transition of power. Electoral violence was also not experience in 2013 due to the fear of a repeat of violence to that experienced in 2007/2008. Important to note is that the increase in the trend of electoral violence has not been linear though 2007 electoral violence was the worse experienced by the country. Mueller argues that politics in Kenya is viewed as a 'winnertakes-all zero-sum ethnic game' since the national economic stake is the prize hence the need for having a fellow coethnic as the president [23]. The notion of winning at all cost, ethnic polarization makes the country violent and fragile. The worst electoral violence was witnessed during the 2007 election that resulted in massive loss of life and property with displacement of thousands within and outside the country [28]. Despite the 2007/2008 unprecedented violence that caught the world's attention and subsequently led to call for reforms, elections in Kenya continue to be marred with violence [24].

Electoral violence in Kenya have serious economic ramification not only in Kenya but also to the landlocked countries of the Great Lakes Region that depend on import and export from the Kenya infrastructural link to the Mombasa port [18]. The violence threatens commercial operations resulting in shortage of commodities within and outside the country subsequently leading to spike in market prices and threat to humanitarian well-being. During the period of electoral violence, the country experiences minimal production and economic losses either through production losses or opportunistic looting as a result of violence [26].

The suggestive typology emanating from literature indicates that electoral violence in Kenya is attributed to: land and ethnicity, culture of violence and impunity, winnertakes-all politics and constitutional and electoral framework; and the impact of electoral violence on the economy. This study found it important to incorporate the possible factors that contribute to electoral violence. This was deemed necessary to lay a foundation for discussing and comprehensively exploring the impact of electoral violence on the economic development of Kenya and to help provide a wider understanding of electoral violence and economic development.

\subsection{Factors Contributing to Electoral Violence}

\subsubsection{Land and Ethnicity}

In the 1900s, the British colonialist evicted the Maasai, Turkana, Nandi and Samburu of the Rift Valley to create the White Highland. In 1939, the British colonialists also forced Kikuyu out of their land in Central Province for the establishment of the White Highlands, forcing the Kikuyus to settle in the Rift Valley [69]. The colonialists particularly recruited the Kikuyu from Central Province as agricultural labourers to work on the White Highland in the Rift Valley. Following independence, some of the agricultural labourers took advantage of the land scheme offered by President Jomo Kenyatta (a Kikuyu) and bought the land [26]. When Jomo Kenyatta became the president, more Kikuyus settled in the Rift Valley and they were later 'given' the land by the President Jomo Kenyatta [50, 69]. Historically this meant that a majority of the people perceived to be of the Rift Valley did not have ancestral land. While the situation was largely maintained till 1992 following the first multi-party elections, politically instigated violence forced Kikuyu farmers out of their farms and this provided a prime opportunity for some politician to re-establish majimbo (a federal system based on regional ethnicity) [69]. Supporters of majimbo propelled for acquisition and retention of land based on the history of migration and settlement and the return of the 'outsider' to their ancestral land. This targeted the Kikuyu community leading to a rift between the Kalenjins and the Kikuyus [50, 69].

During President Daniel Arap Moi's (a Kalenjin) regime, the Kalenjins were allowed to settle in the Mau Forest but they were later expelled from the forest during President Kibaki's (a Kikuyu) two regimes in 2003 and 2008. They felt aggrieved being that they were 'given' the land by President Moi. While the remaining Kalenjins in the Mau Forest had relied on the Prime Minister Raila Odinga (a Luo) to support them based on their political alliance to Raila's political party in 2007, this eventually failed leading to a rift between the Kalenjins and Luos [78]. The salient ethno-regional identities reinforced historical land grievances and political exclusion (Cheeseman, 2008) poses a threat to violence when used as a tool for campaign.

Ethno-regional animosity also started when Jomo Kenyatta banned creation of opposition party associated with the Luo ethnic group [41]. The fall out between President Jomo Kenyatta and Vice President Oginga Odinga in 1966, assassination of prominent Luo leaders, the banning of Odinga's KPU and his detention in 1969 made the Luo Nyanza region to be in conflict with the Kenyatta regime [43, 73]. The post-independence political bargains were marred with ethnic cleavage and the insularity of the governing elite [67] that seemed to have spilled over to the multiparty era. Ethnic clashes of the 1990s are agued to be the forerunner of the 2007 electoral violence between the Kikuyu and the Kalenjin communities in the Rift Valley region that was majorly defined by ethnic violence unlike the state perpetrated violence in Kisumu [49]. This is in line with the principal strands of violence in operation in Kenya as postulated by Branch and Cheeseman [46] that electoral violence involves targeting of members of ethnic communities assumed to be supporters of the government but also that of the state police and the rival militia against those protesting the result of the election. 


\subsubsection{Culture of Violence and Impunity}

Culture of violence refers to "the system of norms, values or attitudes which allow, make possible or even stimulate the use of violence to resolve any conflict or relation with another person" [81]. Impunity refers to the exemption of those who committed unlawful acts from accountability and legal punishment [74]. Under culture of impunity "government officials, the police, military and ordinary citizens break the law without fear of punishment, for there is a shared understanding that each person will be silent about the other's abuses as long as the favour is returned" [74]. Prolonged political violence reinforces impunity, lawlessness and fear among the populace even after the end of conflict $[61,79]$. This provides a fragile environment for electoral process as it is easier to mobilize individuals along conflict lines [61]. Violation of human rights by states apparatus are also associated with such societies resulting into the tendency of a section of the society and non-state armed groups to use violence as a measure of conflict resolution [59, 81]. Political parties use political militia and criminal groups including vigilante, to carry out violence against opponents [57, 59]. Corruption, violation of human rights and encouragement of political violence all constitute impunity [57]. A state of lawlessness by the government officials leads to evasion of responsibility for criminal committed [63].

Governments also play a role in stimulating electoral violence by jailing political opponents, forcing their rivals into exiles or through assassinations during electioneering period thereby escalating anger that provide a prime opportunity for violence [45].

\subsubsection{Winner-Takes-all Politics}

Electoral violence is a tool used for intimidation and disempowering of political rival [71]. In Kenya, elections are very competitive as they do not only designate leadership but also a source of power and wealth [16, 22].

While Kenya is as a democratic country which promulgated its new constitution in 2010 , there seem to be an element of patrimonialism aligned to the party politics. The right to rule is "ascribed to a person rather than an office" and political relations are personal based on loyalty and dependence [47]. This resonates to Kenya politics where those close to the political party leader both in government and opposition are rewarded based on party loyalty. As such, it sparks grievance within parties especially during elections within political parties and political appointments. Communities aligned to the 'winners' and 'losers' of the elective, non-elective posts and party leader's endorsement equally experience political 'representation' or 'let-down' to the national stake.

Patrimonialism and neopatrimonialism politics affects free and fair elections which is fundamental in democracy. Patrimonialism has a potential to encourage electoral violence since it thrive on marginalising a majority of the population and entrenches corruption and culture of impunity [59]. In neopatrimonialism, there is a mix of clientelism and patronage both of which involve securing politic support through the exchange of public goods and service [53]. Clientelism is primarily personal involving patron-client relationship where the client provides political support for a reward. In clientelism, the patrons buy votes and engage in ethno-regional enticement for political support [47, 53]. In patronage, there is a high-level political relation with the clients. The client provides political support in return of public utilities. In addition, voting is used as a means of obtaining material reward as voters tend to favour politicians from their own ethnic groups to secure more reward [53]. Neo-patrimonial politics creates a state of social unrest due to insecurity that exists with regards to unpredictable government operations. This further poses a threat to peaceful political transition [53].

In Africa, most political parties do not embrace diversity but reflect ethnic cleavage [66]. Ethnic-cleavage have been personalised limiting the political space for a fair political competition [55]. Kenya politics is rooted along ethnic blocks as voting happens along ethnic background hence the tendency of favouritism of the ethnic group aligned to the ruling presidency $[29,71]$. Ethnic cleavages reinforce ethnoregional politics and winner-takes-all politics. The product of this strategy is marginalized communities that further worsen based on successive government from the same ethnic region. For instance, during President Kenyatta regime, the concentration of resources and retention of senior government positions among the Kikuyu ethnic community frustrated the Luo, Kalenjin, Luhya, Kamba and Maasai ethnic communities [48].

\subsubsection{Constitutional and Electoral Framework}

Smith [80] argues that electoral violence is due to lack of constitutional and institutional reforms since the advent of multi-party system of politics. Huntington [60] states that there exists a gap between high level political participation and electoral institutions that make the electoral institutions succumb to highly competitive election process leading to political instability in developing nations. Electoral violence is used to contest over the rules governing elections to ensure uncertainty over legitimacy and transparency. Therefore, it is used in regimes with weak institutions that rule governing authority hence the quest for a status quo [16]. Electoral violence is more likely to occur in countries that practice majoritarian voting as these institutions are predicted by theories likely to provoke violence when large ethno-political groups are excluded from power [59].

In Kenya, the polling day is usually characterised by calmness that slowly dissipate as the counting process starts due to fear of rigging. In 2007, the chairperson of the then Electoral Commission of Kenya admitted that he feared that his returning officers were manipulating the electoral results coming from the constituency level [46]. This demonstrates a lack of trust on electoral institutions as depicted by demonstrations and riots organised by the Orange Democratic Movement, the main opposition party, on numerous occasions in the aftermath of elections [46]. Weak institutions have also been observed within the judiciary 
systems due to diminished public trust on how cases involving the government are handled [23].

\subsection{Economic Impact of Electoral Violence}

\subsubsection{Manipulation of Economic Policy to Shape Economic Cycle Prior to Elections}

Government expenditure increases during election period when incumbents use policy instruments for their re-election [70]. This results to a displacement effect which is disruptive to the economy [70]. Electoral expenditures also increase because elections are expensive as seen in the case of Kenya, where all political aspirants must pay registration and nomination fees to their respective political parties and also to the electoral commission during registration of candidature for a specific political party. In addition, the winner-takes-all politics as explained by Mueller [23] makes political aspirant to use all means to win elections. The government might also manipulate the economy prior to an election in order to benefit the incumbents and their parties [68]. This implies that prior to the election the economy becomes political, gradually expands and later contracts after election by applying a short-term economic expansion [51, 68]. Tufte [37] states that political business cycle in some states such as the United States is aligned to politics of the day since it is characterised by short-term management of economic hurdles including inflation and underemployment and flow of fiscal transactions. The manipulation attempt is often done to boost the incumbent's political future especially in regards to wages and taxes [84]. Manipulation of the economy may be reflected in increased government expenditure, transfer to wage earners, wage rate to government employees and employment in the public sector since these expenditures are under the control of the government [56]. Other critics [3] state that testing the hypothesis that the governments tweak the fiscal policy to lure votes is difficult. Drazen [52] also question whether it is a mere coincidence that governments often reduce taxes or increase spending close to election. The Economist [90] argues that while the governments might try to manipulate the economy, they seldom succeed since it is not sustainable.

Economic growth and related opportunities such as employment increase when there is tax, regulatory and monetary reforms [83]. These can be seen in the formation of economic policies by the government which not only impact on the GDP per capita income but also have a bearing on international trade [89].

\subsubsection{Reduced Willingness to Invest Due to Violence}

Presidential candidates are a major determinant of the nature of how the economy will fare on [75]. Uncertainty is usually high during elections and this often has an impact in the economy both before and immediately after the elections [44]. Internal and external investors study market trends to determine profitable and sustainable ventures [64]. Investors wait to gauge the possible outcomes of the future economic policies before they can launch a major project [17]. Investors make decisions based on what they read or hear and therefore depending on their expectations, they will drive the market up or down to stir the economy [82]. Prior to the August 2017 general elections, firms scaled down on production, investors held on to their cash and the neighbouring countries redirected their cargo to Tanzania ports [62]. The nullification of the August 2017 elections greatly affected investors. The Nairobi Security Exchange (NSE), the largest stock market in East and Central Africa, lost KES 92billion ( $\sim$ US\$920 million) in market capitalization in the day after the nullification of the August 2017 election by the Kenya Supreme Court [4]. The NSE further lost KES 38 million ( US\$380,000) on the subsequent trading session [4] and halted trade due to the sharp fall in share price [34]. During the same period the private sector (Kepsa) lost KES 700billion ( US\$7,000 million) due to business uncertainty majorly due to the nullification of elections, disruption of transport and industrial operations during the campaign period [4].

Participation at the NSE by foreigners gradually slowed down at $57.9 \%$ in June, $49.1 \%$ in July, $57.1 \%$ in August and $55.7 \%$ in September compared to $63.4 \%$ in May and $72.4 \%$ in April [34]. To deal with some of these investment challenges, many Kenyan companies budget for four years and then one year of little or no returns because of the expected significant reduction in business volumes [2].

\subsubsection{Inflation}

Economies can suffer shocks connected to election seasons, a phenomenon especially prevalent in developing countries [86]. Government can create unanticipated inflation in order to reduce unemployment although this does not affect unemployment systemically except in the period following elections $[42,65]$. This is usually attributed to the "inability of the government to pre-commit to price stability" prior to the onset of electoral period [42]. Government spending usually increase during election making the economy vulnerable to inflation rather than economic growth [64]. Government electoral spending, private spending or money printing leads to a lot of money flooding the market [75-76]. These acts supposedly put pressure on central banks who is in charge of monetary stability [9]. For example, The Financial Times reported that there was increased inflation in the 2011 elections held in Thailand, forcing the central bank to move "aggressively to keep it under control" [9]. Similarly, the Central Bank of Kenya had to do away with excess money in the country's economy because of formal and informal spending, voter bribing and other costs related to the elections [77]. The central bank should have the ability to design and implement monetary policy free from political influences since its autonomy is a key instrument devised to control inflation [58]. Political budgetary cycles explain why most developing economies experience sudden rise in inflation and large debt series incurred during election period [70]. In Kenya, the highest ever inflation rate of $46 \%$ was recorded in 1993 just after the 1992 general election when the country first embraced multi-party politics [17]. The inflation was mainly attributed to dramatic political reforms 
accompanied by ethnic clashes in some parts of the country leading to fall in agricultural production [17].

\subsubsection{Disruption of Economic Activities}

The prolonged uncertainty created by elections is likely to slow down the growth of the economy in various ways: (i) the wait and see attitude by investors slows down investment, (ii) travel advisories due to perception of insecurity during the election period impact key sectors such as tourism, (iii) the stock market index is adversely affected by negative market sentiments and (iv) disruptions to many other economic sectors such as hotels, transport, wholesale and retail as people stay away from work [72]. Government cut its economic growth forecast for 2017 from 5.7\% to 5.5\% while the growth for 2016 was $5.9 \%$ [2]. $47 \%$ of the manufacturer cut down jobs to reflect deterioration business environment [2]. This is because, according to the Kenya Association of Manufacturers, 6 out of 10 manufacturers saw no or negative growth in the economy and could not therefore sustain high labour cost [4]. The deceleration in the manufacturing industries implies that there are fewer job opportunities and less revenue to the government [27].

\section{Method}

This is a case study design that employed both qualitative and quantitative approaches to explore the impacts of electoral violence on economic development of Kenya. The case study method was adopted in this research to help the researcher go into greater depth in analysing the research topic which is a new topic in politics with limited existing literature. The exploratory nature of this study in relation to electoral violence in a country that is just coming out of elections which were highly contested and also marred with electoral violence made a case study most appropriate to explore the research topic. The design was also suitable for the study as it narrowed down the target location of the study to Kenya for an in-depth analysis. The research is descriptive based on the diverse literature which aims to describe the case of Kenya.

The quantitative aspect of the research was through a deskbased study based of secondary data from World Bank and KNBS from 1992, 1997, 2002, 2007, 2013 and 2017 general elections. The already existing data provided statistical growth or decline in the economy during the months and years of elections and non-election period. In addition, semistructured interview guide was used to conduct in-depth interviews with business people to corroborate World Bank and Kenya National Bureau of Statistics (KNBS) findings. Five participants were engaged in the in-depth interview and they were purposively identified. These were business individual living in Nairobi which is the capital city of Kenya and are engaged in different types of businesses including construction industry, medium scale retail business, transport sector and farming. The researcher identified the first participant to engage in the interview and the rest were identified through snowballing. While this is the case, the researcher interviewed individuals from different ethnic tribes for diverse perspectives and experience due to the strong political and ethnic division in Kenya.

An analysis of World Bank Economic Global Economic Monitor data was conducted for the respective electoral years to determine the impact of electoral violence on economic development. While the World Bank Data was analysed on an annual basis, Leading Economic Indicators data from KNBS was analysed on a monthly basis with focus on the election month and two months before and after election. A comparison of the monthly and annual data was conducted and this was further enriched with findings from the in-depth interviews. A comparative analysis was also done on years that elections were considered peaceful and this included the 2005 and 2010 constitutional referendum and 2002 and 2013 general elections. Data from the semi-structured interview guide was synthesized in thematic including; measures business people take before, during and after election; what shapes their attitude towards risk, perceptions towards investment and how experience has shaped their business. The World Bank and KNBS data has been presented in graphical and tabular form while the findings from the indepth interview have been incorporated in the discussions.

The various sources of data were used for the purpose of triangulation and to detect and reduce bias. This is also in addition to the possible strengths and weaknesses of the various data hence the need to minimize on possible bias and maximize on representation and generalization of findings. It would have also been of additional benefit to conduct a survey to get a wider view of the business people in the various sector e.g. insurance, transport industry and small traders especially in the informal settlements that are usually affected during electoral violence, though this was not possible due to inadequate time and financial resources. Access to economic data was also limited to World Bank and KNBS as they were readily and freely available.

The research observed the University of Birmingham's Code of Practice for Research by adhering to integrity and accountability; intellectual property and copyright; conflict of interest and ethical review. The data and study findings have been used solely for the purpose of this study. It is important to acknowledge that elections in Kenya are characterised by strong ethnic divisions and therefore the researcher strived to eliminate possible ethnic bias that might deviate from the objective of the research by ensuring various ethnic groups were represented in the indepth interviews. Participants who were interviewed signed voluntary informed consent prior to the interview and they voluntarily granted the researcher permission to quote them in this study. Their views have been solely used for the purpose of this study. The researcher acknowledges the sensitivity of the research topic including ethnicity as a cause of violence in the Kenyan context and therefore the researcher did not engage in any form of ethnic soliciting of view and articulating of literature that might seem biased and cause or flare conflict. 


\section{Results}

\subsection{Stock Market}

Stock market is important for economic and financial development as they may affect economic activities through the creation of liquidity [6]. This is because business institutions prefer long-term access to capital thereby attracting profitable investments leading to a long-term economic growth [6]. While this is the case, it is important to note that liquidity may hamper economic growth as it may reduce saving rates leading to uncertainty on savings thereby weakening investors' commitment [6]. Important to note also is that when stock markets are accurately valued they improve efficacy of maximizing growth by aligning the interest of owners and managers thereby spurring economic growth [6]. Stock market is of significance to investors since they expect good returns from their investments. During elections, the stock market is of importance to policy makers and investors since they influence the level of economic activities thereby determining economic development especially in the critical periods of election [25].

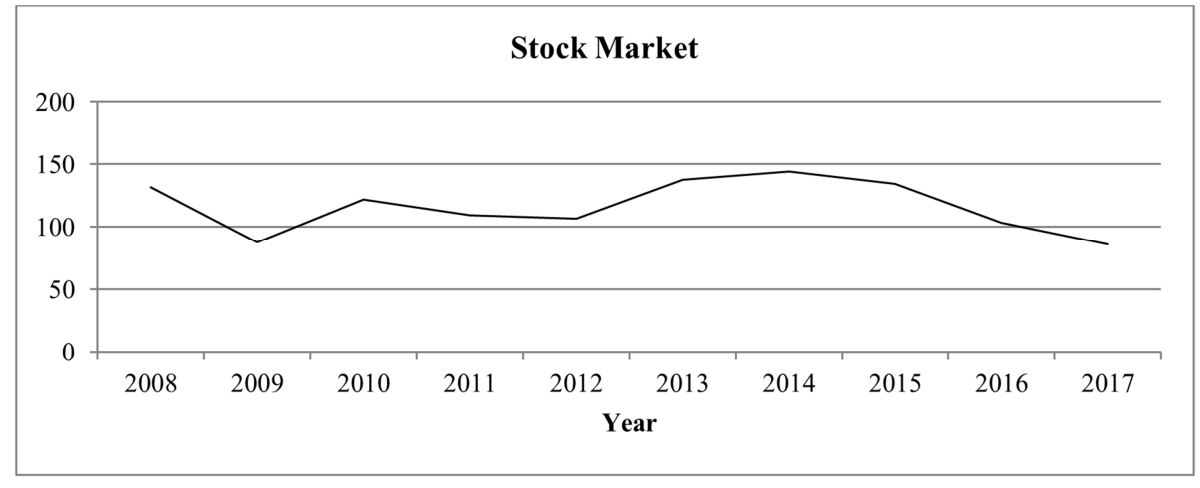

Figure 1. The Stock Market Performance-2008-2017.

World Bank Data - Note: Data only available from 2008

The stock market decreased during election year of 2017 while it increased during 2010 and 2013 elections in reference to Figure 1. While this is the case, it was also noted that there has been a general fluctuation in the stock market even during the years before elections. The stock market sharply increased in 2010 by $39 \%$ in comparison to the previous year. A similar increase of $29 \%$ was also noted in 2013. 2010 was the year when the constitutional referendum was conducted while 2013 general election was considered peaceful.

A comparison of the above World Bank data with the Kenya National Bureau of Statistics (KNBS)/Nairobi
Securities Exchange (NSE) data in Table 1 indicate that there was notable decreased in the number of transactions during the month of election in 2007 while there was an increase in transactions in the month of election for the years 2010, 2013 and 2017. A sharp increase was also noted a month before and a month after 2010 referendum. In 2013, the increase was gradual two month before and after the election month.

The monthly data in Table 1 is in tandem with the annual data though a variation is noted is in 2017 where the stock market decreased in 2017 annual data but increased in the monthly data. This can be attributed to the two general elections that were conducted in 2017 within a span of 60 days.

Table 1. Number of Nairobi Securities Exchange Transactions by Month during Election Years.

\begin{tabular}{llllllll}
\hline \multirow{2}{*}{ Yr./Mon. } & \multicolumn{2}{l}{ NSE - Number of Transactions by Month } & & & & \\
\cline { 2 - 7 } & Jun & Jul & Aug & Sep & Oct & Nov & Dec \\
\hline 2007 & & & & & 86,422 & 73,780 & $* 53,106$ \\
2010 & 46,790 & 92,226 & $* 99,368$ & 94,472 & 46,890 & & \\
2013 & & & & & & \\
2017 & 27,101 & 26,045 & $* 32,405$ & 25,337 & $* 18,978$ & 26,534 & 20,716 \\
\hline
\end{tabular}

Table 1. Continued.

\begin{tabular}{|c|c|c|c|c|c|}
\hline \multirow{2}{*}{ Yr./Mon. } & \multicolumn{5}{|c|}{ NSE - Number of Transactions by Month } \\
\hline & Jan & Feb & Mar & Apr & May \\
\hline 2007 & 69,754 & 74,615 & & & \\
\hline \multicolumn{6}{|l|}{2010} \\
\hline 2013 & 32,416 & 31,529 & $* 34,443$ & 39,859 & 39,727 \\
\hline 2017 & & & & & \\
\hline
\end{tabular}

Kenya National Bureau of Statistic Data; *Election Month 


\subsection{Official Exchange Rates - Kenya Shilling per US Dollar}

The exchange rate greatly influences the country's economy since it is considered one of the important factors in the occurrence of financial crises [19]. Uncertainty surrounding elections usually results in uncertain exchange rates as a result of increased errors in forecasting especially when different candidates pursue different policies [8]. The volatility of exchange rates relative to their expected values during election period is of significance to investors in determining their investment plans in relation to the expected profit margins.

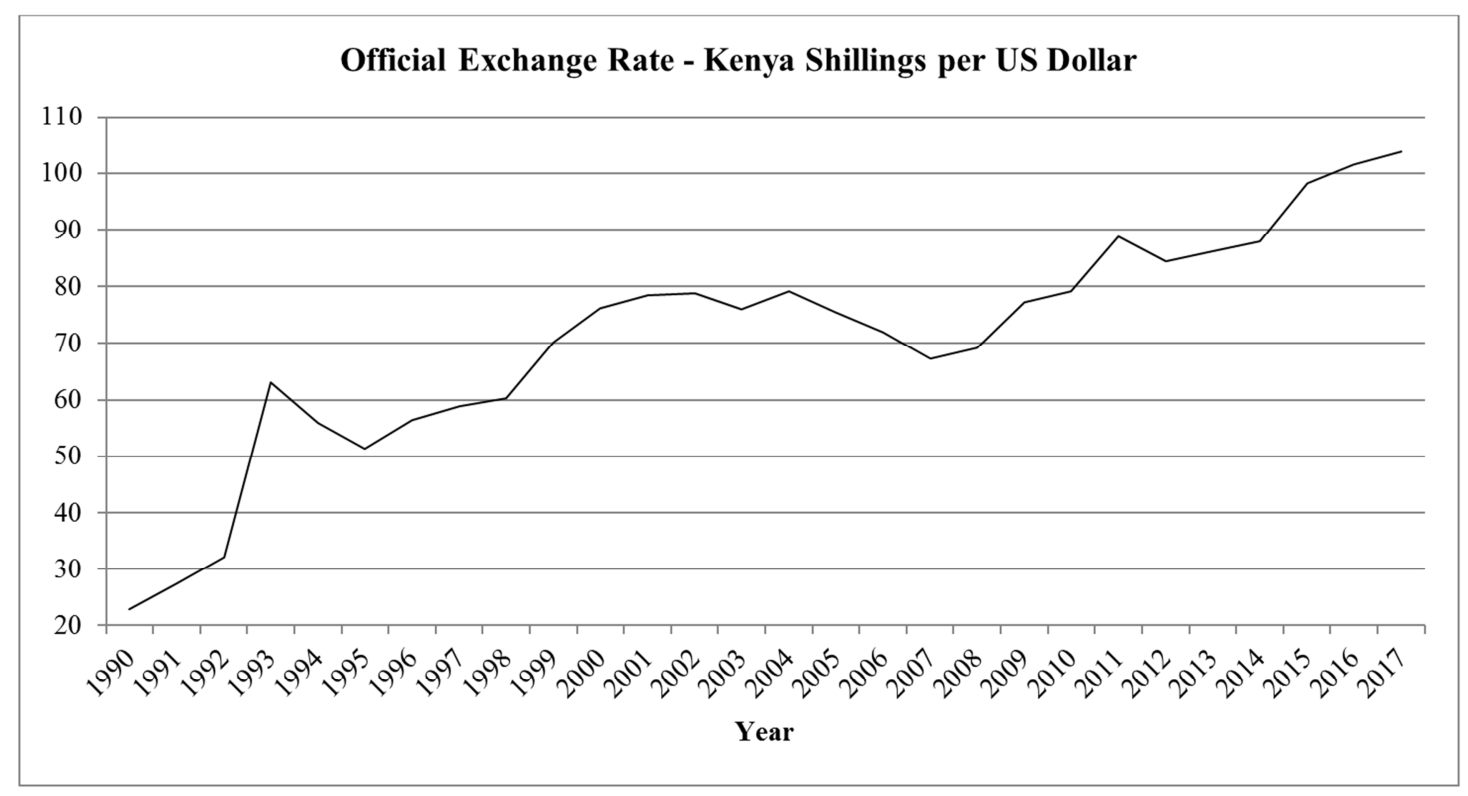

Figure 2. Official Exchange Rate - 1990-2017.

\section{World Bank Data}

The World Bank data in Figure 2 indicate that there has not been significant decrease in the official exchange rate during election years apart from 2005 and 2007. An increase was also recorded during the years of peaceful elections 2002, 2010 and 2013 save for 2005 which had a slight decrease in comparison to the previous year.
A comparison of the above data with the KNBS data in Table 2 indicates that the Kenya Shilling decreased during the election months in comparison to the months before elections and thereafter stabilized. While this is the case, the shilling increased in August 2010 which was the month when the referendum was conducted.

Table 2. Official Exchange Rates by Month during Election Years.

\begin{tabular}{llllllll}
\hline \multirow{2}{*}{ Yr./Mon. } & \multicolumn{2}{l}{ Official Exchange Rate by Month } & & & \\
\cline { 2 - 8 } & Jun & Jul & Aug & Sep & Oct & Nov & Dec \\
\hline 2007 & 81.92 & 80.23 & $* 81.07$ & 80.68 & 80.79 & & \\
2010 & & & & & & & \\
2013 & 103.5 & 103.88 & $* 103.56$ & 103.13 & $* 103.4$ & 103.25 & 103.1 \\
2017 & & & & & & & \\
\hline
\end{tabular}

Table 2. Continued.

\begin{tabular}{|c|c|c|c|c|c|}
\hline \multirow{2}{*}{ Yr./Mon. } & \multicolumn{5}{|c|}{ Official Exchange Rate by Month } \\
\hline & Jan & Feb & Mar & Apr & May \\
\hline 2007 & 70.56 & 70.64 & & & \\
\hline \multicolumn{6}{|l|}{2010} \\
\hline 2013 & 87.611 & 86.24 & $* 85.64$ & 93.82 & 84.15 \\
\hline 2017 & & & & & \\
\hline
\end{tabular}

Kenya National Bureau of Statistic Data; *Election Month

\subsection{Import Merchandise}

Import and export are important to the development of a country because they generate foreign exchange and revenue to the government. Import and exports open and expand economies to both businessmen and individual consumers thereby contributing to significant economic growth [33]. Import results to competition and brings variety to the domestic markets benefiting consumers while exports enlarge 
markets for domestic production which benefits business people [31]. International trade through import and export is important since it exposes domestic traders to best practices thus improving capital inputs and boosting productivity [33].

Import and export can be further analysed by the use of Balance of Trade (BOT) which is the difference between the value of a country's import and export for a given period (Investopedia, no date). Balance of Trade is therefore used to measure the relative strength of a country's economy. When the Balance of Trade is further broken down, a country that imports more goods and services than its exports in terms of value has a trade deficit and a country that exports more goods and services than its imports has a trade surplus [33]. This implies that a country with a large trade deficit borrows money to pay for its goods and services while a country with trade surplus lends money to deficit countries [33].

Elections in Kenya are coupled with a slowdown in economic growth, increased unemployment and high cost of credit which affects the manufacturing industry [1]. This in turn affects the import and export industry.

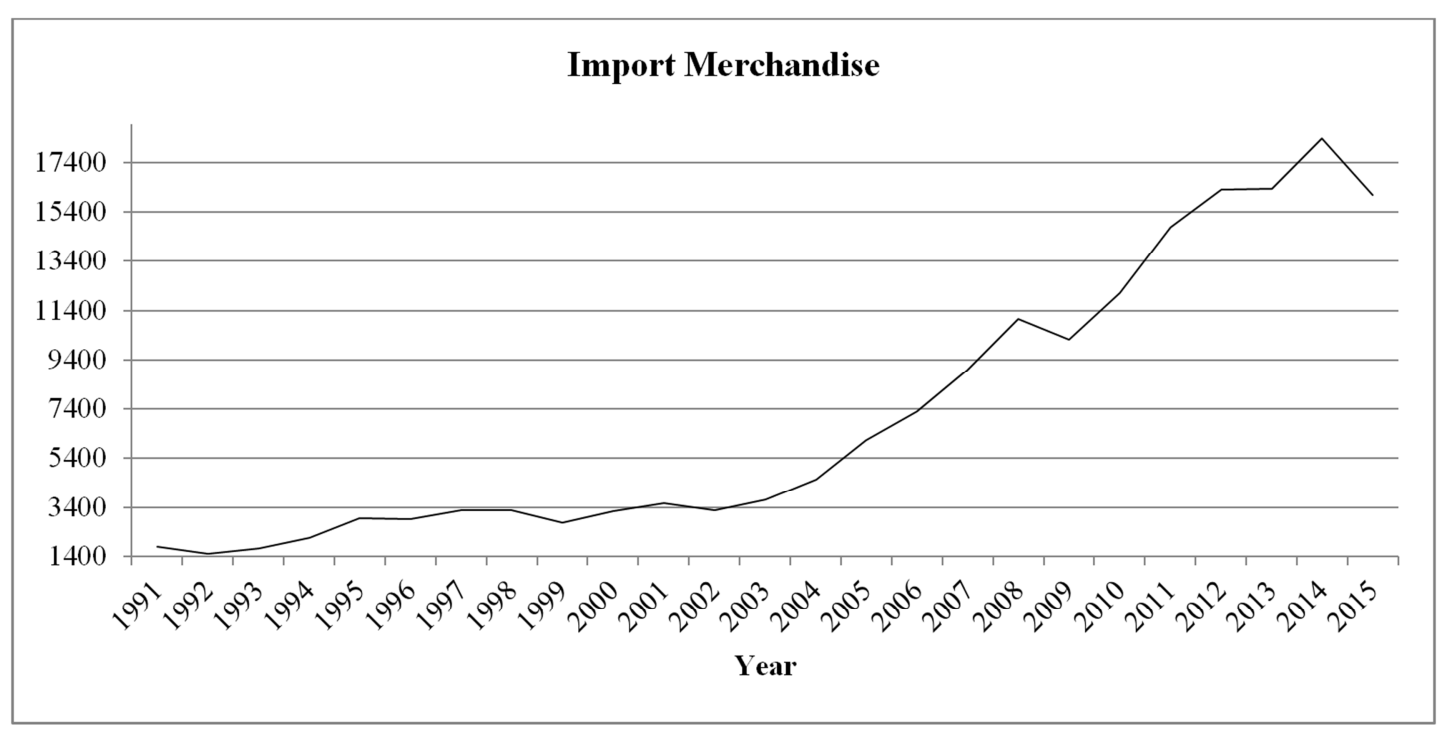

Figure 3. Import Merchandise - 1991-2015.

World Bank Data - Note: No data for 2016 and 2017

The data in Figure 3 indicates that there was a decrease in import during the election years of 1992 and 2002 in comparison to the previous years, while there was an increase in the subsequent election years including the peaceful election years. Increase in import was also noted in the year
2008 which had unprecedented post-electoral violence.

A comparison of the above with the KNBS data in Table 3 indicates that there was a decrease in import during all the election months including 2010 August when the referendum was conducted and March 2013 when Kenya had peaceful elections.

Table 3. Import by Broad Economy by Month during Election Years.

\begin{tabular}{lllllll}
\hline \multirow{2}{*}{ Yr./Mon } & \multicolumn{2}{l}{ Import by Broad Economy - Kshs. Million } & \multicolumn{1}{l}{} \\
\cline { 2 - 6 } & Jun & Jul & Aug & Sep & Oct & Nov \\
\hline 2007 & & & & & $59,049.00$ & $57,732.00$ \\
2010 & $79,208.2$ & $80,566.2$ & $* 73,016.2$ & $88,640.5$ & $82,679.8$ & \\
2013 & & & & & & \\
2017 & $143,013.54$ & $165,573.49$ & $* 144,294.70$ & $141,180.00$ & $* 147,900.00$ & $138,151.00$ \\
\hline
\end{tabular}

Table 3. Continued.

\begin{tabular}{|c|c|c|c|c|c|c|}
\hline \multirow{2}{*}{ Yr./Mon } & \multicolumn{6}{|c|}{ Import by Broad Economy - Kshs. Million } \\
\hline & Dec & Jan & Feb & Mar & Apr & May \\
\hline 2007 & $* 37,757.00$ & $64,341.00$ & $58,051.00$ & & & \\
\hline 2010 & & & & & & \\
\hline 2013 & & $130,764.50$ & $116,417.6$ & *108,816.01 & $118,664.19$ & $113,71.52$ \\
\hline 2017 & $141,810.00$ & & & & & \\
\hline
\end{tabular}

Kenya National Bureau of Statistic Data; *Election Month

\subsection{Exports Merchandise}

Exports and imports are regulated through tariffs and quotas in order to protect the local industries. Export promote growth, however, growth and export are hindered by instability arising from frequent disruption in production [21]. Some of the 
disruptions can be as a result of electoral violence.

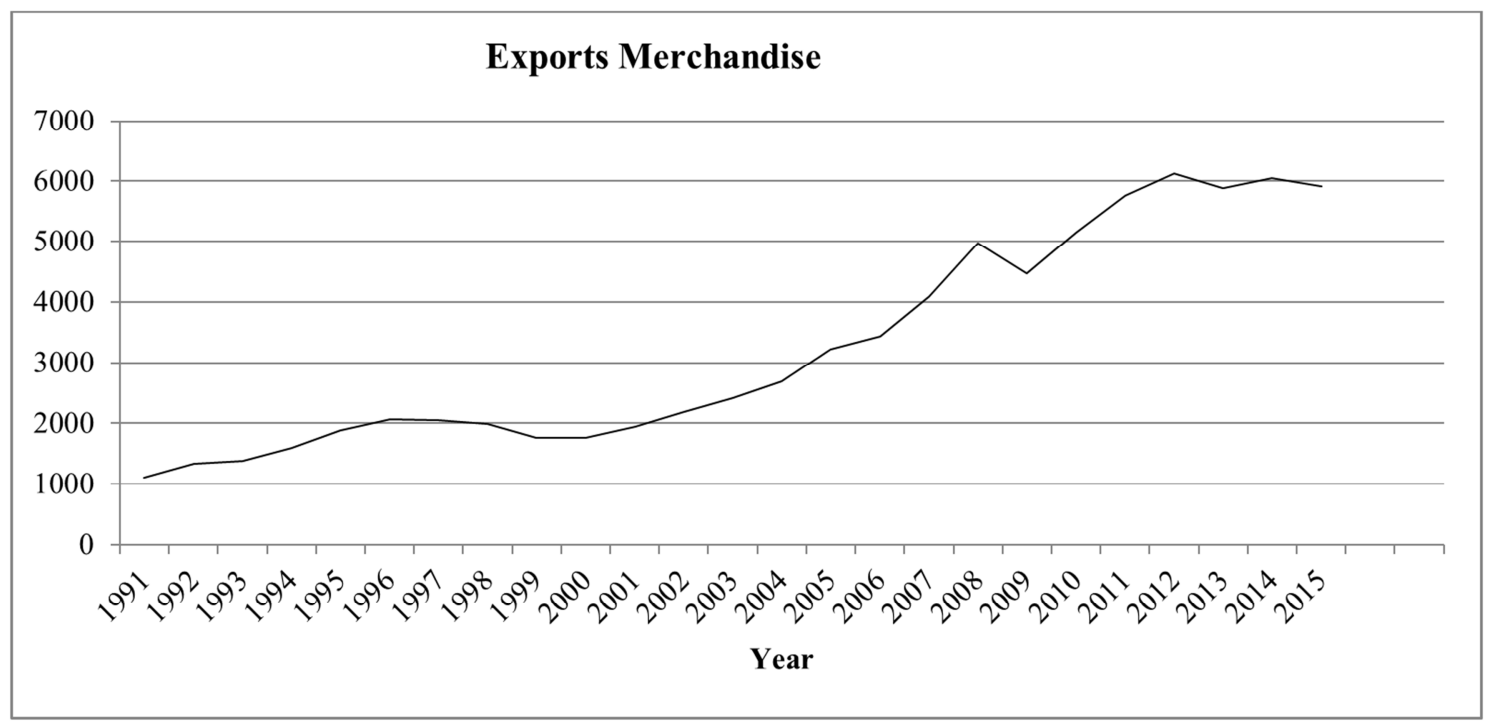

Figure 4. Exports Merchandise - 1991-2015.

World Bank Data: Note - Data not available for 2016 and 2017

Figure 4 indicates that there was a slight reduction in export in 1997 and 2013. All the other election years had an increase in export. While this is the case, there was a reduction in export in the month of elections for all the years as indicated in Table 4 and this improved in subsequent month's post-election month.

Table 4. Export by Broad Economy by Month during Election Years.

\begin{tabular}{llllllll}
\hline Yr./Mon. & \multicolumn{2}{l}{ Export by Broad Economy - Kshs. Million } & & & \\
\cline { 2 - 8 } & Jun & Jul & Aug & Sep & Oct & Nov & Dec \\
\hline 2007 & & & & & 23,516 & 24,970 & $* 16,940$ \\
2010 & 31,756 & 33,175 & $* 28,735$ & 32,578 & 29,902 & & \\
2013 & & & & & & & \\
2017 & $46,416.44$ & $47,369.84$ & $* 37,198.96$ & $46,341.00$ & $* 43,195.00$ & $45,182.00$ & $44,587.00$ \\
\hline
\end{tabular}

Table 4. Continued.

\begin{tabular}{|c|c|c|c|c|c|}
\hline \multirow{2}{*}{ Yr./Mon. } & \multicolumn{5}{|c|}{ Export by Broad Economy - Kshs. Million } \\
\hline & Jan & Feb & Mar & Apr & May \\
\hline 2007 & 22,768 & 31,277 & & & \\
\hline 2010 & & & & & \\
\hline 2013 & $42,970.51$ & $43,145.97$ & $* 35,793.32$ & $45,546.4$ & $39,824.58$ \\
\hline 2017 & & & & & \\
\hline
\end{tabular}

Kenya National Bureau of Statistic Data; *Election Month

\subsection{Consumer Price Index Price and Inflation Rate}

Consumer Price Index (CPI) is not only of interest to the voters during an election period but also to the political aspirants since it influences the cost of living that is a key agenda during the campaign and voting period. During elections, market expectations shift with heighten expectation on possible changes in the fiscal policy [29]. If the policies take effect, they could lead to higher productivity and subsequent growth rate and high inflation; they could also lead to higher debt [29]. High inflation is a sign of macroeconomic imbalance which reduces economic growth and prospects of future growth thereby hampers development [38]. While this is the case, low inflation in itself does not guarantee economic growth [38]. 


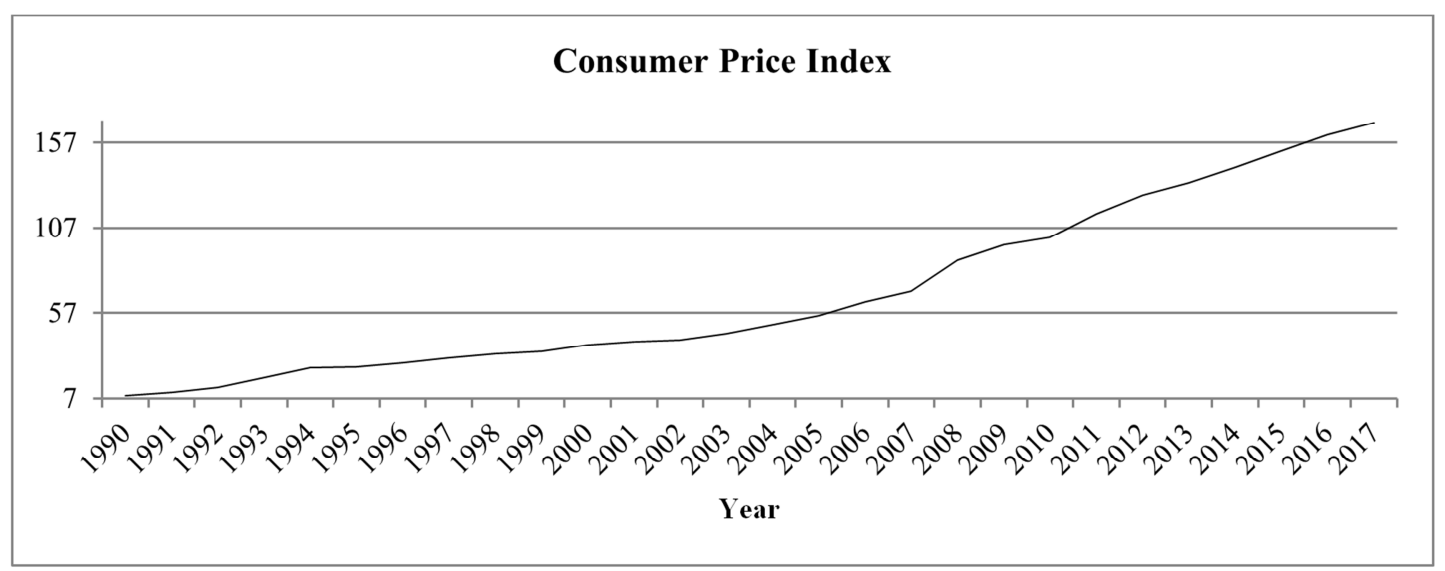

Figure 5. Consumer Price Index - 1990-2017.

\section{World Bank Data}

There was an increase in the Consumer Price Index (CPI) during all the election years. While this is the case, it can be noted that the CPI has had a gradual increase in all nonelection years as depicted in Figure 5. The same was also seen during the election months where the consumer price index increased as shown in Table 5. All the peaceful and non-peaceful election months had an increase in the CPI. The increase was gradual before and after the election months while it fluctuated in 2017 after the August elections possibly due to the repeat elections.

Table 5. Consumer Price Index by Month during Election Years.

\begin{tabular}{|c|c|c|c|c|c|c|c|}
\hline \multirow{2}{*}{ Yr./Mon. } & \multicolumn{7}{|c|}{ Consumer Price Index by Month } \\
\hline & Jun & Jul & Aug & Sep & Oct & Nov & Dec \\
\hline 2007 & & & & & 229.99 & 233.28 & $* 239.81$ \\
\hline 2010 & 105.61 & 105.98 & $* 106.25$ & 106.74 & 106.97 & & \\
\hline 2013 & & & & & & & \\
\hline 2017 & 185.39 & 183.6 & $* 184.72$ & 183.66 & $* 182.5$ & 182.08 & 183.05 \\
\hline
\end{tabular}

Table 5. Continued.

\begin{tabular}{|c|c|c|c|c|c|}
\hline \multirow{2}{*}{ Yr./Mon. } & \multicolumn{5}{|c|}{ Consumer Price Index by Month } \\
\hline & Jan & Feb & Mar & Apr & May \\
\hline 2007 & 260.94 & 266.37 & & & \\
\hline \multicolumn{6}{|l|}{2010} \\
\hline 2013 & 135.62 & 136.59 & *137.96 & 139.28 & 139.52 \\
\hline 2017 & & & & & \\
\hline
\end{tabular}

Kenya National Bureau of Statistic Data; *Election Month

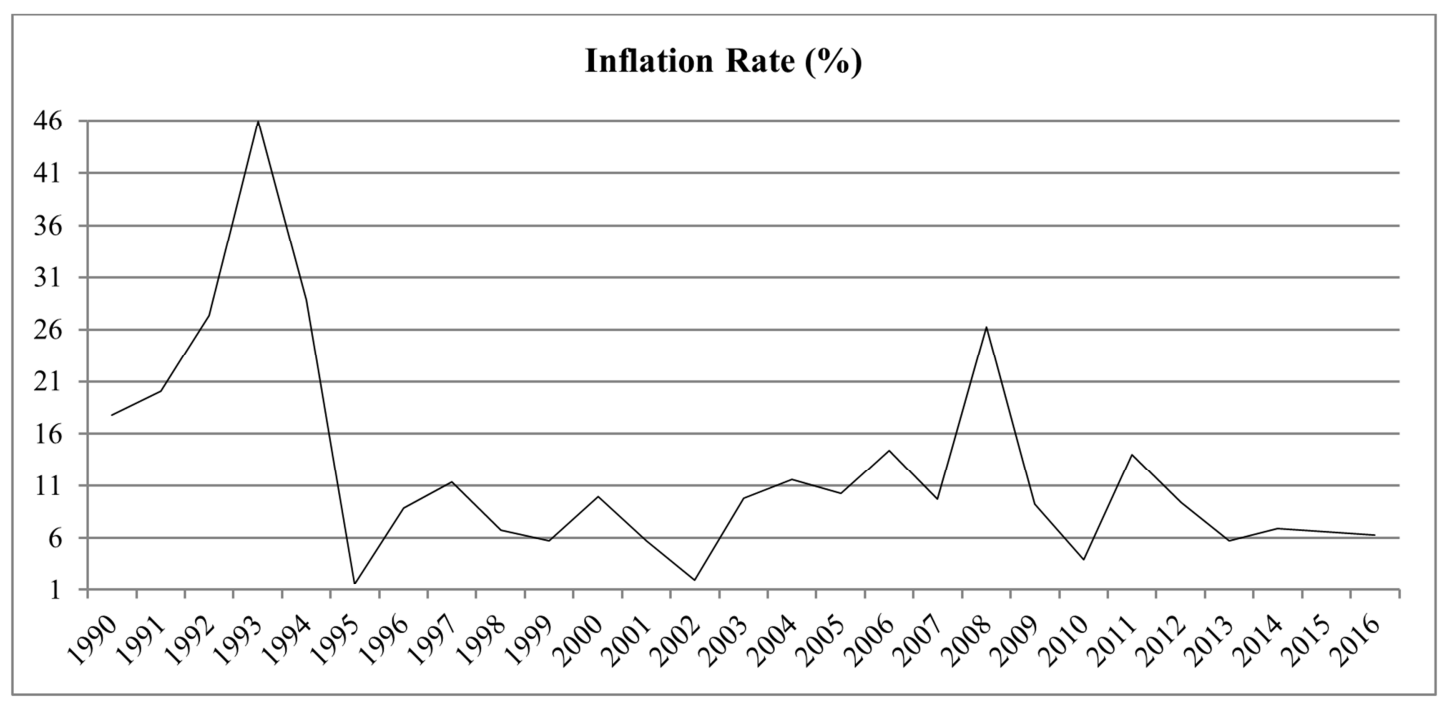

Figure 6. Inflation Rate-1990- 2016. 


\section{World Bank Data}

The inflation rate increased in 1992 and 1997. A sharp increase was also noted in 1993 which was a year after election year. In 2002, there was a sharp decline in inflation compared to all other years and this could have possibly been as a result of the peaceful transition of government. The constitutional referendum years of 2005 and 2010 were also noted to have had a sharp decline in inflation consumer price. While there was a decrease in inflation in 2007 in comparison to 2006 , there was a sharp percentage increase in 2008 from $9.8 \%$ (2007) to $26.2 \%$ (2008). Figure 6 depicts a fairly contained inflation between 1995 and 2007 in comparison to the years between 1990 and 1994.

The monthly data in Table 6 revealed that inflation increased during the months of election and also in the months following elections for the year 2007/2008 and $2012 / 2013$. Inflation was fairly high before and during the August 2017 and this was also observed in September 2017 and thereafter it subsided. Inflation gradually decreased in August 2010 which was the month of referendum, and a reduction was also noted in the subsequent months.

Table 6. Inflation Rate by Month during Election Years.

\begin{tabular}{|c|c|c|c|c|c|c|c|c|c|c|c|c|}
\hline \multirow{2}{*}{ Yr./Mon. } & \multicolumn{12}{|c|}{ Inflation Rate by Month } \\
\hline & Jun & Jul & Aug & Sep & Oct & Nov & Dec & Jan & Feb & Mar & Apr & May \\
\hline 2007 & & & & & 10.6 & 11.8 & $* 12$ & 18.2 & 19.2 & & & \\
\hline 2010 & 5.43 & 5.03 & $* 4.69$ & 4.40 & 4.12 & & & & & & & \\
\hline 2013 & & & & & & & & 3.67 & 4.45 & $* 4.11$ & 4.14 & 4.05 \\
\hline 2017 & 9.21 & 7.47 & $* 8.04$ & 7.06 & *5.72 & 4.73 & 4.5 & & & & & \\
\hline
\end{tabular}

Kenya National Bureau of Statistic Data; *Election Month

\section{Discussions}

\subsection{Inflation}

Kenya elections are characterised by fairly high inflation which tend to rise months before elections with impact felt months after elections [17]. Consumer Price Index as a measure of inflation rate was found to gradually increase in all election and non-election years and the same applied for electoral and non-electoral months. This trend was not unique to Kenya and is in tandem with Nordhaus' model which refers to an inflation surge immediately before and/or after elections. This was characteristic in the case of Kenya where the inflation reduces two years after elections before it picks again a year after elections. This further explains why office holders would want to boost the economy before the elections without any concurrent inflation; and the inflationary implication of the money policy too far in advance also results into a boom too early thereby higher level of inflation [3]. Tufte argue that the pressure for reelection opportunity by politicians is enhanced by production of inflation and unemployment outcomes [37]. The business people interviewed indicated that inflation significantly affect their businesses since cost of production becomes high. Oscar Odhiambo who has been in the transport industry for about 20 years stated that "increased inflation affects the cost of petrol and this forces transport operators to increase fares thereby leading to few people opting for taxi as a means of transport". Additionally, construction industries get affected due to the high construction cost that force contractors to review the already approved bill of quantities for negotiation with their clients. Hillary Makhulu a contractor for over 15 years reported that "the price hike impacts on transportation, cost of materials and labour which leads to high risk for losses especially on the already approved construction projects. It also delays projects completion due to the need to temporary halt some projects until the market prices are fair". It is important to note that inflation sharply decreased in 2002, 2005, 2010 and 2013, all of which experienced peaceful elections.

When inflation is viewed in light of economic development, an increase in inflation means a decline in the purchasing power due to price increase of goods and services. This reduces consumption and further decrease the GDP. High inflation can affect investment since it creates uncertainty and it can also affect export since they become more expensive, further decreasing the GDP [32].

\subsection{Reduced Willingness to Invest}

Stock market is of significant interest to investors and their predictability is of great importance to businessmen in making critical decisions on profitable investment.

Political events have an influence on the stock market performance and volatility and when the political uncertainty is resolved, there is a positive subsequent change [10]. It is evident from the World Bank data that the stock market reduced in electoral year (2017) that experienced violence while it increased during the peaceful elections (2010 and 2013) and this can be attributed to high level of uncertainty that is characterised by highly contested general elections in Kenya $[16,22]$. This was alluded in the in-depth interviews which elicited that there was poor performance in investment including the money market. James Peter a contractor stated that "returns on investments have been very unpredictable and low due to high level of political uncertainty and violence". Bernadette Muyomi a small holder farmer highlighted some level of optimism in the money market since "the temporary level of volatility of trade is only severely felt with major political decisions such as nullification of elections and thereafter the market 
'normalize"". Beaulieu, Cosset and Essaddam on the other hand argue that that stock market volatility varies with the degree of a firm's exposure to political risk [5]. The larger the international market coverage the lesser the exposure of the firm to political risks associated with poor performance of the stock market [5]. This notion is in agreement with Hillary, Bernadette, James and Oscar's view that the 'big' players in the market are not adversely affected by the volatility of the stock market and political uncertainty including violence. Of interest to note was the drop in the number of stock market transactions during the months prior to election month. This could be linked to a fairly higher level of certainty after the election period in comparison to before and during elections. This is also evidenced by the increase in the stock market during the years of peaceful elections. Literature revealed that billions of shillings were lost in the months of August 2017 [4, 35] and this could be the possible reason for the decreased performance in 2017. Conversely the monthly data revealed that the number of transactions during the same month was far much better in comparison to the two months before and after the month of elections. Therefore, this may imply that while the financial value of the stock market reduced possibly due to withdrawal of part of the stock from the market to minimize risk, investors were still willing to continue to trade. In addition, stock market being a form of trade largely pegged on time, it is still possible that the overall month of August, 2017 could have had a higher performance. This implies that the high loss being referenced in the literature is attributed to losses recorded on the day of the nullification of the election results by the Supreme Court [4]. The nullification of the August 2017 presidential elections surprised investors and a sharp sell-off caused trading to be briefly halted [20]. Most investors postponed their investments plans waiting for a political settlement [35].

The volatility and complexities of the stock market performance makes is challenging to corroborate the literature and the data findings of the August 2017 election month [30] since performance are based on myriad of factors whose impact can be felt on a day and even in just few hours. Despite this, it is of significance to try to avert electoral violence related losses in a bid to boost the economy of the county.

\subsection{Disruption of Economic Activities}

Import and export are key economic indicators that contribute towards economic growth of Kenya. The findings reveal that there has not been any significant reduction in the import of merchandise during elections years though there was a reduction in import during all electoral months. Ito [12] argues that low foreign reserves may force the government to brake the economy in order to curb import; this has not been the case of Kenya. Conversely, there has been an increase in import in monetary value in comparison to export even during the election years hence the possible fairly stable and low foreign reserve import.

Export can remain promising amidst elections as exports account to the identity of the national component of the GDP [14]. It is no surprising that there was very minimal negative impact of the elections on the export during election years; the exports were observed to increase during the election years apart from 1997 and 2013. The premier timing of elections as explained by Kayser [14] could have a bearing on the increase in export despite the elections since constitutional provision on the timing of election in Kenya constrain political behaviour that might have a significant bearing on exports. In addition, exports are also resistant to reverse causation and therefore the economic expansion as a result of the increased export increases import trade [14]. This is an important phenomenon as to why the increase in export during the election years has continued to propel trade. While this is the case, it is important to note that the major exports linked to the agricultural sector including coffee, tea and flowers reduce significantly during the month of election in addition to food production as a result of land related conflicts $[17,28]$ and thereafter stabilised in the subsequent months. The reverse causation of import and export was experienced during the months of election where both import and export decreased.

Exchange rates are an important contributor to the economic growth in relation to import and export of merchandise. The monthly KNBS data on the exchange rate do not draw any systematic pattern of increase or decrease before and after election month. This can imply that the Central Bank of Kenya strives to maintain the monetary stability even amidst the inflation [9]. The Central Bank of Kenya (CBK) policy towards the exchange rate adjusts (weakening or strengthening of the shilling) in line with the economic factors including trade, production and investment. This implies that the Central Bank endeavours to keep foreign exchange reserves equivalent to import cover [35]. The CBK further emphasised in the September 2016 circular that a competitive exchange rate ensures that the interest of both importers and exporters are balance and therefore the movement of the exchange rate cannot be classified as good/strong or bad/weak if it is adjusting to the economic factors. The CBK argument is therefore reflective of the increase in import and exports during the years of elections despite the fluctuation of the shilling during the month and year of election as depicted in World Bank and KNBS data.

The increase in import and export was noted to largely increase during the election year though this can be deduced to be as a result of the annual aggregation of data from all the major industries. Finding from the textile, agricultural and tourism sector seems contrary as these sectors are affected by insecurity as a result of electoral violence. The textile industry recorded a $60 \%$ decline of which two-thirds was related to the August 2017 elections [2]. Production for the main staple, maize, dropped from 25.4million bags in 1992 to 24.3 million in 1993 [17]. These findings are a reflection of the monthly data on import and export. When electoral violence is anticipated, travel advisory is issued leading to reduced investment in tourism [27]. Domestic tourism also 
shrinks further impacting on tourism and hotelier industries [27].

\subsection{Manipulation of the Economy}

Elections are costly in Kenya since a lot of financial resources are required during the campaign period and significant amount of money is also required for the registration processes with the electoral commission. This makes the elections to be highly contested because aspirant cannot afford to lose after the huge investment. This results in an inflationary effect as the government expenditure increases.

It was not clearly evident on how the Kenya government could be manipulating the economy during the electoral period though the inflationary effect could be an implied outcome. The stability of the exchange rate and regulation of the same by the Central Bank does not provide adequate information that would indicate that the government manipulate the economy to its favour.

Information obtained from the interviews revealed that businesses are generally affected during elections and this extends when results are contested. There is slowdown in business and little investment as a result of anticipated risks that are also not likely to be absorbed by the insurance industry in case of losses or damage. To deal with the situation, the business people layoff some staff to cut down on the production cost, increase the prices of commodities to cater for any eventualities and temporarily close down businesses during the high risk days in anticipation of results announcement and mass reaction to the same as expressed by Hillary, Oscar and Stephen in their interview. Majority of the business people who have over 10 years of experience reported that they strive to boost their profit within the first four years and months before the campaigns commence and thereafter slow down operations to study the market trends including security in order to minimize on loses. Their attitude towards risk has been shaped by extensive knowledge and experience of the Kenya politics and business trends in relation to the degree of risk one is able to absorb. This has enabled the people in business to quickly bounce back after election.

\section{Conclusions}

Elections cause a general slowdown in economic activities during the month of election as evidenced by the monthly data. This is also evidenced by the information obtained from the interviews conducted with people in business. The degree of risk that business people are willing to take during election period denotes that the economy still progresses during the months towards elections but slows in the actual month of election. While this is the case, 'uncertainty is higher during the counting and announcement of results and the associated contestation of results' as stated by Hillary Makhulu. Investors also study the market over years to determine the appropriate time to boost or slowdown their production as evidenced by the annual increase in import and export. While the literature reveals that there is significant impact of elections on the economy, this is a reflection of the electoral month which is significantly affected in comparison to the electoral year.

Economic activities were noted to remain stable and even increased during the years of peaceful elections in comparison to years of electoral violence. Import, export and the stock markets increased during the years of peaceful elections and inflation was also noted to reduce in 2002 and 2005 and during the months of elections of 2010 and 2013 which were all years of peaceful elections.

The findings of this study therefore reveal that significant economic development can be achieved with peaceful elections. This also requires the government to take lead in promoting the independence of electoral institutions and halting politically instigated violence in a bid to win elections at all cost.

\section{Recommendations}

There is need for the government to deliberately improve on the electoral reforms in order to promote free and fair election and subsequently minimize electoral violence. This requires the need to build trust among Kenyans before, during and after polls. While electronic voting has been implemented, the advent of improved technology calls for real-time voting and subsequently tallying of results to minimize errors in an environment where there is high level of mistrust in addition to the highly contested elections.

It will also be of great importance if the government of Kenya including the citizens can have a greater level of awareness on the impact of electoral violence on the economy. If billions were lost within few hours as a result of electoral violence, then this reveals that the economy of Kenya can gradually grow in an upward trend if such violence can be eliminated altogether.

Voter education on the need to preserve life and property is imperative even amidst the fight for free and fair elections. This calls for embracing of fair and transparent electoral processes amongst the political contenders, the electoral institutions and institutions of justice which should be autonomous to operate in a fair and just manner.

The notion of the winner-takes-all politics makes the country vulnerable to electoral violence. This therefore call for the government and the citizens to be accommodative and tolerant to embrace reconciliation and a supportive attitude towards nation building since all have a stake in the development of the country.

There is need for more research on the impact of electoral violence on development to ensure higher analysis of dynamics of conflicts in relation to development. This will help countries that experience electoral violence to formulate and implement policies that focus on free, fair and peaceful elections that are align to the development agenda of the country. 


\section{Acknowledgements}

I acknowledge the use of World Bank and Kenya National Bureau of Statistics data from their open database. I am grateful for the free access to this data from both institutions.

\section{Disclosure Statement}

I declare that this research is my original work and has not been presented for publication in any journal. There is not potential conflict of interest linked to this research

\section{References}

[1] Achuka, V. (2017) Police, Prison Officers Get Pay Rise amid Delays. Standard Digital [online], Saturday $29^{\text {th }}$ July. Available from: https://www.standardmedia.co.ke/article/2001249573/policeprison-officers-get-pay-rise-amid-delays [Accessed 23rd April, 2018].

[2] Aglionby, J. (2017) Kenya Election Re-run Puts Further Damper on Economy. Financial Times [online], Wednesday $4^{\text {th }}$ October. Available from: https://www.ft.com/content/ebebe0bc-a213-11e7-9e4f7f5e6a7c98a2 [Accessed 14th May, 2018].

[3] Alesina, A., Cohen, D. G., and Roubini, N. (1992) "Macroeconomic Policy and Elections in OECD Democracies". The National Bureau of Economic Research: Economics and Politics, 4 (1):1-30. Available from: https://doi.org/10.1111/j.1468-0343.1992.tb00052.x [Accessed January $\left.21^{\text {st }}, 2018\right]$.

[4] Alushula, P. (2017) Politics: Top 10 Numbers that Defined Economy During 2017 Elections. Standard Digital [online], Tuesday $31^{\text {st }} \quad$ October. Available from: https://www.standardmedia.co.ke/business/article/2001258908 /top-10-numbers-that-defined-economy-during-2017-elections [Accessed $3^{\text {rd }}$ May, 2018].

[5] Beaulieu, M. C., Cosset, J. C., and Essaddam, N. (2005) The Impact of Political Risk on the Volatility of Stock Returns: The Case of Canada. Journal of International Business Studies, 36: 701-718. Available from: https://www.jstor.org/stable/3875281 [Accessed 15th July, 2018].

[6] Demirguq-Kunt, A. and Ross, L. (1996) Stock Markets, Corporate Finance, and Economic Growth: An Overview. The World Bank Economic Review, 10 (2): 223-239. Available from: https://www.jstor.org/stable/3990061 [Accessed 2nd September, 2018].

[7] Floros, C. (2008) The Influence of the Political Elections on the Course of the Athens Stock Exchange 1996-2002. Managerial Finance, 34 (7): 479-282. Available from: https://doi.org/10.1108/03074350810874433 [Accessed $17^{\text {th }}$ July, 2018].

[8] Garfinkel, M. R.; Glaze, A.; and Lee, J. (1999) Election Surprises and Exchange Rate Uncertainty. Economics and Politics, 11 (3): 255-274. Available from: http://www.economics.uci.edu/ mrgarfin/papers/ep-exrate.pdf [Accessed 3rd September, 2018].

[9] Garriga, A. C., and Rodriguez, C. M. (2017) Stepping up
During Elections: Independent Central Banks and Inflation. Available from: http://dx.doi.org/10.2139/ssrn.2989162 [Accessed 25th July, 2018].

[10] Hooi. L. H. (2010) Political General Election and Stock Performance: The Malaysian Evidence. Research in Mathematics and Economics, Chapter 11: 111-120. Available from:

https://www.researchgate.net/publication/274376318 Political General_Election_and_Stock_Performance_the_Malaysian_ $\bar{E}$ vidence? [Accessed $23^{\text {rd }}$ July, 2018].

[11] Human Rights Watch (2002) Playing With Fire: Weapons Proliferation, Political Violence, and Human Rights in Kenya. New York: Human Rights Watch. Available from: https://www.hrw.org/reports/2002/kenya/ [Accessed $14^{\text {th }}$ January, 2018].

[12] Ito, T. (1991) International Impacts on Domestic Economy: A Case of Japanese General Elections. Journal of International Money and Finance, 10: S73-S89. Available from: http://www.nber.org/papers/w3499 [Accessed 23rd July, 2018].

[13] Kanyinga, K. (2014) Kenya Democracy and Political Participation: A Review by AfriMAP. Open Society Initiative for East Africa and the Institute for Development Studies (IDS), Nairobi: Open Society Initiative for East Africa. Available from: https://www.opensocietyfoundations.org/reports/kenyademocracy-and-political-participation [Accessed 14th January, 2018].

[14] Kayser, M. A. (2006) Trade and the Timing of Elections. British Journal of Political Science, 36 (3): 437-457. Available from: https://www.jstor.org/stable/4092257 [Accessed 13th January, 2018].

[15] Kenya National Bureau of Statistics. Available from: https://www.knbs.or.ke [Accessed 16 ${ }^{\text {th }}$ July, 2018].

[16] Khadiagala, G. (2010) Causes and Consequences of Election Related Violence in Africa. In: Preventing and Managing Violent Election-Related Conflicts: Exploring Good Practices. Conference Proceeding Report. EISA's 4th Annual Symposium, 17 -18 November, 2009. Available from: https://www.eisa.org.za/pdf/symp09cp.pdf [Accessed 28th July, 2018].

[17] Kinuthia, K. (2017) How Elections Have Devastated Kenya's Economy, Cost of Living Since 1992. Business Daily [online], Wednesday $23^{\text {rd }}$ August. Available from:

https://www.businessdailyafrica.com/markets/marketnews/Ho w-elections-affect-the-cost-of-living-and-economicgrowth/3815534-4068306-gw8k1w/index.html [Accessed $27^{\text {th }}$ May, 2018].

[18] Kirimi, J. K., and Njuguna, C. N. (2014) Impact of Election Violence on Socio-Economic Situation in Africa: A Case of Kenya. Mediterranean Journal of Sciences, 5 (5): 263-272. Available from: Doi:10.5901/mjss.2014.v5n5p [Accessed 27 ${ }^{\text {th }}$ July, 2018].

[19] Korkmaz, S. (2013) The Effect of Exchange Rate on Economic Growth. Balikesir University Available from: https://www.researchgate.net/publication/311588566 [Accessed $3^{\text {rd }}$ September, 2018].

[20] Kottasová, I. (2017). Kenya Election Shocker Sparks Fears over Economy. Cable News Network [online], Friday $1^{\text {st }}$ September. Available from:

https://money.cnn.com/2017/09/01/news/economy/kenyaelection-economy/index.html [Accessed $22^{\text {nd }}$ May, 2018]. 
[21] Ksoll, A.; Macchiavello, R. and Morjaria, A. (2014) Guns and Roses: Flowering Exports and Electoral Violence in Kenya. Available from:

http://cega.berkeley.edu/assets/miscellaneous_files/107_ABCA - MORJARIA flowers gnr.pdf [Accessed 3rd September, 2018].

[22] Kuhne, W. (2010) The Role of Elections in Emerging Democracies and Post-Conflict Countries: Key Issues, Lesson Learned and Dilemmas. International Policy Analysis. Berlin: Friedrich Ebert Stiftung. Available from: http://library.fes.de/pdf-files/iez/07416.pdf [Accessed 17th January, 2018].

[23] Mueller, S. D. (2008) The Political Economy of Kenya's Crisis. Journal of East African Studies, 2 (2): 185-210. Available from: http://doi.org/10.1080/17531050802058302 [Accessed 25th August, 2018].

[24] Ngesa, M. (2008) The Roots of Kenya's Crisis. Development and Cooperation [online] Monday $21^{\text {st }}$ January. Available from: https://www.dandc.eu/en/article/root-causes-kenyaspost-election-crisis [Accessed $13^{\text {th }}$ January, 2018].

[25] Nzioka, M. M. (2018) Critical Analysis on Determinants of the Nairobi Stock Market Performance for Kenyan Forms During General Elections. Maters Thesis. Mount Kenya University. Available from: http://hdl.handle.net/11915/1902 [Accessed 2nd September, 2018].

[26] OHCHR (2008) Report from the United Nations Office of the High Commissioner for Human Rights Fact-Finding Mission to Kenya, 6-28 February, 2008. Available from: https://www.ohchr.org/documents/press/ohchrkenyareport.pdf [Accessed 14th January, 2018].

[27] Otieno, D. (2016) Election and Economy: Why Economy Slow Down in Election Years. Daily Nation [online], Saturday $23^{\text {rd }}$ April. Available from:

https://www.nation.co.ke/newsplex/kenya-election-2017gdp/2718262-3173194-moknsqz/index.html [Accessed 25th March, 2018].

[28] Oucho, J. O. (2013) Undercurrents of post-Election Violence in Kenya: Issues in the Long-Term Agenda. In: A Chapter for Democratic Gains and Gaps: A Study of 2007 Kenyan General Elections (Available from: https://warwick.ac.uk/fac/soc/crer/research/mariecurie/afrobra in/oucho/publications/john_oucho.pdf [Accessed on $6^{\text {th }} \mathrm{Feb}$ 2018].

[29] Restrepo-Echavarria, P. (2017) The Election's Effect on Expected Inflation. On the Economy Blog [online], Monday $23^{\text {rd }}$ January. Available from: https://www.stlouisfed.org/onthe-economy/2017/january/elections-effect-expected-inflation [Accessed 3rd, September, 2018].

[30] Rioba, G. O. (2003) Predictability of Ordinary Stock Returns at the Nairobi Stock Exchange in Kenya. Masters Thesis: University of Nairobi. Available from: http://erepository.uonbi.ac.ke/bitstream/handle/11295/22281/R ioba Predictability $\% 20$ of $\% 20$ ordinary $\% 20$ stock\%20returns $\%$ 20 at $\% 20$ the $\% 20$ Nairobi $\% 20$ stock $\% 20$ exchange $\% 20$ in $\% 20 \mathrm{Ke}$ nya.pdf? sequence $=3$ [Accessed $19^{\text {th }}$ July, 2018].

[31] Schneider, B. R. (2004) Business Politics and the State in Twentieth-Century Latin America. In: Soi, N., Koskei, I., Buigut, K., and Kibet, J. (2013) Effect of International Trade on Economic Growth in Kenya. European Journal of Business and Management. 5 (10): 131-137. Available from: https://www.researchgate.net/publication/295402223

[Accessed 8th September, 2018].

[32] Smith, M. The Relationship between Inflation and Economic Growth (GDP): An Empirical Analysis. Available from: https://www.ivoryresearch.com/writers/melanie-smith/ [Accessed $9^{\text {th }}$ September, 2018].

[33] Soi, N., Koskei, I., Buigut, K., and Kibet, J. (2013) Effect of International Trade on Economic Growth in Kenya. European Journal of Business and Management. 5 (10): 131-137. Available from: https://www.researchgate.net/publication/295402223 [Accessed 8th September, 2018].

[34] SPAU (2017) Unravelling the Impact of the Political Impasse on the Kenyan Economy: A Vehicle to Articulate Development Issues and Foster Dialogue. UNDP Policy Brief. Issue No: 2/2017. Available from: http://www.ke.undp.org/content/kenya/en/home/library/strateg ic-policy-advisory-unit-/policy-brief--impact-of-politicalimpasse-on-economy.html [Accessed $17^{\text {th }}$ May, 2018].

[35] The Central Bank of Kenya (2016) A Strong Kenya Shilling: The Exchange Rate and the Performance of the Kenya Shilling. Available from: https://www.centralbank.go.ke/wpcontent/uploads/2016/09/Response-Performance-of-theShilling.pdf [Accessed 24 ${ }^{\text {th }}$ July, 2018].

[36] The World Bank, Kenya (2017). Kenya Overview. Available from: http://www.worldbank.org/en/country/kenya/overview [Accessed $13^{\text {th }}$ January, 2018].

[37] Tufte, E. R. (1978) Political Control of the Economy. Princeton: Princeton University Press. Available from: https://www.amazon.com/Political-Control-EconomyEdward-Tufte/dp/0691021805 [Accessed 15th May, 2018].

[38] UN (2017) Inflation Rate. Department of Economic and Social Affairs. Available from: http://www.un.org/esa/sustdev/natlinfo/indicators/methodolog y_sheets/econ_development/inflation_rate.pdf [Accessed 3rd September, 2018].

[39] Widner, J. A. (1993) The Rise of a Party-State in Kenya: From "Harambee!" to "Nyayo!" Berkeley: University of California. Available from: http://ark.cdlib.org/ark:/13030/ft9h4nb6fv/ [Accessed $3^{\text {rd }}$ February, 2018].

[40] World Bank. Economic Monitor Data. Available from: http://www.worldbank.org/en/research/brief/economicmonitoring [Accessed $4^{\text {th }}$ February, 2018].

[41] Africa Watch. (1993) Divide and Rule: State-Sponsored Ethnic Violence in Kenya. New York: Human Rights Watch. Available from:

https://www.hrw.org/reports/1993/kenya1193.pdf [Accessed 8th February, 2018].

[42] Alogoskoufis, S. G., Lockwood, B., and Philippopoulos, A. (1992) Wage Inflation, Electoral Uncertainty and the Exchange Rate Regime: Theory and UK Evidence. The Economic Journal, 102 (415): 1370-1394. Available from: https://www.jstor.org/stable/2234795 [Accessed August 3rd, 2018].

[43] Amutabi, M. N. (2009) Beyond Imperial Presidency in Kenya: Interrogating the Kenyatta, Moi and Kibaki Regimes and Implications for Democracy and Development. Kenya Studies Review, 1 (1): 55-84. Available from: http://kessa.org/yahoo_site_admin/assets/docs/3_MN_AMUT ABI.140160111.pdf [A Accessed14 ${ }^{\text {th }}$ January, 2018] . 
[44] Answers Africa (2018) Kenyan Elections: Implications for the Economy. Available from: https://answersafrica.com/kenyanelection-implications-economy.html [Accessed $20^{\text {th }}$ August, 2018].

[45] Beaulieu, M. C., Cosset, J. C., and Essaddam, N. (2005) The Impact of Political Risk on the Volatility of Stock Returns: The Case of Canada. Journal of International Business Studies, 36: 701-718. Available from: https://www.jstor.org/stable/3875281 [Accessed 15th July, 2018].

[46] Branch, D. and Cheeseman, N. (2008) Democratization, Sequencing, and State Failure in Africa: Lesson from Kenya. African Affairs, 108 (430): 1-26.

[47] Bratton, M., and Van de Walle, N. (1994). "Neo Patrimonial Regimes and Political Transitions in Africa". World Politics, 46 (4): 453-489. Available from:

https://www.jstor.org/stable/2950715 [Accessed $15^{\text {th }}$ January, 2018].

[48] Cheeseman, N. (2015) Democracy in Africa. Cambridge: Cambridge University Press. pp. 143-170.

[49] Cheeseman, N. (2008) The Kenya Elections of 2007: An Introduction. Journal of East African Studies, 2 (2): 166-184. Available from: http://doi.org/10.1080/17531050802058286 [Accessed 22nd August, 2018].

[50] Cussac, A. (2009) “Kibaki Tena?” The Challenges of a Campaign. In: Lafargue, J. (ed.). The General Elections in Kenya, 2007. pp. 55-104. Dar es Salaam: Mkuki na Nyota Publishers Ltd. Available from: https://www.researchgate.net/publication/289799397 Kibaki_Ten a_The_challenges_of_a_campaign [Accessed 16th January, 2018].

[51] De Leon, C. P., and Canes-Wrone, B. (2014) Elections, Uncertainty and Economic Outcomes. Available from: https://web.stanford.edu/group/sssl/cgi-bin/wordpress/wpcontent/uploads/2013/12/conferencepost.pdf [Accessed 17th July, 2018].

[52] Drazen, A. (2001) The Political Business Cycle After 25 Years. NBER Macroeconomics Annual 2000, Cambridge: MIT Press. 15: 75-138. Available from: http://www.nber.org/chapters/c11055 [Accessed 16th July, 2018].

[53] Erdmann, G., and Engel, U. (2007) Neo Patrimonialism Reconsidered: Critical Review and Elaboration of an Elusive Concept. Commonwealth \& Comparative Politics, 45 (1): 95119. Available from:

https://doi.org/10.1080/14662040601135813 [Accessed $15^{\text {th }}$ April, 2018].

[54] Fischer, J. (2002) Electoral Conflict and Violence: A Strategy for Study and Prevention. IFES White Papers 2002-01. Available from: http://unpan1.un.org/intradoc/groups/public/documents/untc/u npan019255.pdf [Accessed 16 ${ }^{\text {th }}$ March, 2018].

[55] Fortman. B. D. G. (2000) "Elections and Civil Strife: Some Implications for International Election Observation." In: Abbink, J. and Hesseling, G. Election Observation and Democratization in Africa. New York: Palgrave Publishers.

[56] Frey, B. S. and Schneider, F. (1979) An Econometric Model with an Endogenous Government Sector. Public Choice, 34 (1): 29-43. Available from:

https://www.jstor.org/stable/30023079 [Accessed 17th January, 2018].
[57] Githinji, M. and Holmquist, F. (2012) Reform and Political Impunity in Kenya: Transparency without Accountability. African Studies Review, 5 (1): 53-74. Available from: http://www.jstor.org/stable/41804128 [Accessed 26 ${ }^{\text {th }}$ August, 2018].

[58] Goodfriend, M. (2007) How the World Achieved Consensus on Monetary Policy. The Journal of Economic Perspective, American Economic Association, 21 (4): 47-68. Available from: http://www.nber.org/papers/w13580.pdf [Accessed 23rd July, 2018].

[59] Høglund, K. (2009) Electoral Violence in Conflict-Ridden Societies: Concepts, Causes, and Consequences. Terrorism and Political Violence, 21 (3): 412-427. Available from: https://doi.org/10.1080/09546550902950290 $\left[\right.$ Accessed $19^{\text {th }}$ January, 2018].

[60] Huntington, S. P. (1968) Political Order in Changing Societies. London: Yale University Press. Available from: https://projects.iq.harvard.edu/gov2126/files/huntington politi cal_order_changing_soc.pdf[Accessed 14th January, 2018].

[61] Jarstad, A. (2008) Dilemmas of War-to-Democracy Transitions: Theories and Concepts. In: Jarstad, A. and Sisk, T. (ed.), From War to Democracy: Dilemmas of Peacebuilding pp 17-36. Available from:

https://doi.org/10.1017/CBO9780511755859.002 [Accessed $23^{\text {rd }}$ January, 2018].

[62] Leftie, P., Ngirachu, J., Ondieki, E., Ringa, M., and Moseti, B. (2017) Kenya's Economic Activity Slows Down Ahead of General Election. The East African [online]. Wednesday $26^{\text {th }}$ July. Available from:

http://www.theeastafrican.co.ke/business/Economic-activityslows-down-ahead-of-General-Election-/2560-4032474syhlq6/index.html [Accessed 2nd March, 2018].

[63] Kelley, K. J. (2018) Corruption, and Impunity Continue to Plague Kenya: US Report. Daily Nation [online]. Saturday $21^{\text {st }}$ April. Available from:

https://www.nation.co.ke/news/Graft-impunity-rife-in-Kenya-US-rights-report-shows/1056-4492156-d2f2scz/index.html [Accessed 26th August, 2018].

[64] Krishnan, R., and Bhattacharya, P. (2014) How Do Elections Affect the Economy? LiveMint E-Paper [online], April 14. Available from: https://www.livemint.com/Politics/RRDNEebSEiPECEiclpqZ $\mathrm{mM} /$ How-do-elections-affect-the-economy.html [Accessed $14^{\text {th }}$ May, 2018].

[65] Kydland, F., and Prescott, E. C. (1977) Rules Rather than Discretion: The Inconsistency of Optimal Plans. Journal of Political Economy, 85 (3): 473-492. Available from: https://www.jstor.org/stable/1830193 [Accessed 17th January, 2018].

[66] Mehler, A. (2007) Political Parties and Violence in Africa: Systematic Reflections against Empirical Background. In: Seifu, T. T. Causes of Electoral Violence: Lessons from the May 2005 Election of Ethiopia. Norway: University of Tromso. Available from: https://munin.uit.no/bitstream/handle/10037/3981/thesis.pdf?s equence $=2$ [Accessed 22 ${ }^{\text {nd }}$ January, 2018] .

[67] Mohamed, O. O. (2015).Election Violence in Kenya: A Case of Nakuru 1992-2008. Masters Thesis, Kenyatta University. Available from: http://ir-

library.ku.ac.ke/handle/123456789/14317 [Accessed $4^{\text {th }}$ January, 2018]. 
[68] Monroe, K. R. (1983) Political Manipulation of the Economy: A Closer Look at the Political Business Cycles. Presidential Studies Quarterly, 13 (1): 37-49.Available from: https://www.jstor.org/stable/27547885 [Accessed 20 ${ }^{\text {th }}$ May, 2018].

[69] Mutua, M. (2008) Kenya's Quest for Democracy: Taming the Leviathan. London: Lynne Rienner Publishers.

[70] Mutuku, C. (2017) How to Measure Election Effect on Kenya's Economy. Business Daily [online], Monday $2^{\text {nd }}$ October. Available from:

https://www.businessdailyafrica.com/analysis/5395484121810-8tg6bn/index.html [Accessed 3rd March, 2018].

[71] Mwagiru, M. (2001) Political and Electoral Violence in East Africa. Friedrich Ebert Stiftung and Centre for Conflict Research. Available from: http://library.fes.de/pdffiles/bueros/kenia/01398.pdf [Accessed 2nd February, 2018].

[72] Nyakera, I. (2017) Kenya's Political Uncertainty to Dent Economic Activity. Business Daily [online], Sunday $10^{\text {th }}$ September. Available from:

https://www.businessdailyafrica.com/analysis/uncertainty-todent-economic-activity/539548-4089894-et6f8fz/index.html [Accessed 14th April, 2018].

[73] Odhiambo-Atieno, E. (2004) Africa's Colonial Legacy, Berg. R. J. and Whitaker, J. S. (ed.), Strategies for African Development. Berkeley: University of California Press.

[74] Opotow, S. (2003) Reconciliation in Times of Impunity: Challenges for Social Justice. Social Justice Research, 14 (2): 149-170. Available from: https://doi.org/10.1023/A:1012888902705 [Accessed $17^{\text {th }}$ February, 2018].

[75] Panta, S. (2017) Economic Impact of Elections. Nepal Economy Forum [online], Tuesday $28^{\text {th }}$ November. Available from: https://nepaleconomicforum.org/neftake/economicimpact-of-elections/ [Accessed $17^{\text {th }}$ May, 2018].

[76] Pourcelot, J. P. (2015) Venezuela: Central Bank Confirms that Money Supply Soared in Weeks Prior to Elections. Focus Economics, [online] Sunday $6^{\text {th }}$ December. Available from: http://www.focuseconomics.com/countries/venezuela/news/in flation/central-bank-confirms-thatmoney-supply-soared-inweeks-prior-to [Accessed 3rd August, 2018].

[77] Ramogi, O. (2017) Spending on Campaigns and Imports has Caused High Price. Daily Nation [online], Friday $3^{\text {rd }}$ March. Available from: https://www.nation.co.ke/oped/opinion/election-campaigns- and-import-has-caused-high-prices/440808-383633454ok7vz/index.html [Accessed 23rd July, 2018].

[78] Rao, E. (2009) August 30 Interview in Roberts, N. J. (2009). In: Roberts, M. J. Conflict Analysis of the 2007 Post-Election Violence in Kenya. New Dominion Philanthropy Metrics. Available from: http://ndpmetrics.com/papers/Kenya_Conflict_2007.pdf [Accessed 17th January, 2018].

[79] Sisk D. Timothy (2009) Pathways of the Political: Electoral Processes after Civil War. In: Seifu, T. T. Causes of Electoral Violence: Lessons from the May 2005 Election of Ethiopia. Norway: University of Tromso. Available from: https://munin.uit.no/bitstream/handle/10037/3981/thesis.pdf?s equence $=2$ [Accessed 22 ${ }^{\text {nd }}$ January, 2018].

[80] Smith, M. The Relationship between Inflation and Economic Growth (GDP): An Empirical Analysis. Available from: https://www.ivoryresearch.com/writers/melanie-smith/ [Accessed $9^{\text {th }}$ September, 2018].

[81] Steenkamp, C. (2005) The Legacy of War: Conceptualizing a 'Culture of Violence' to Explain Violence after Peace Accords. The Commonwealth Journal of International Affairs, 94 (379): 253-267. Available from: https://doi.org/10.1080/00358530500082775 [Accessed 19th January, 2018].

[82] Stinnett, J. (2016) How a Presidential Year Election Can Impact on the Economy. Smart Asset [online], Monday $5^{\text {th }}$ September. Available from:

https://smartasset.com/investing/election-year-impactseconomy [Accessed 5th May, 2018].

[83] Taylor, J. B., and Cochrane, J. H. (2016) (ed.) Central Bank Governance and Oversight Reforms. Stanford: Hoover Institution Press.

[84] The Economist (2015) String-Pushers: Free Exchange. Finance and Economics. Available from: https://www.economist.com/finance-andeconomics/2015/04/18/string-pushers [Accessed $13^{\text {th }}$ May, 2018].

[85] UNDP (2009) Elections and Conflict Prevention: A Guide to Analysis. Planning and Programming Democratic Governance Group: Bureau for Development Policy.

[86] Wallner, P. (2012). Elections and Inflation: In Search of a Political Business Cycle. Department of Economic. Lund University. 